\title{
Keefektifan Model Pembelajaran Number Head Together (NHT) Berbantu Media Puzzle Terhadap Hasil Belajar Matematika
}

\author{
Veni Tri Kurnia $^{1 *}$, Aries Tika Damayani², Kiswoyo ${ }^{3}$ \\ 1,23 Pendidikan Guru Sekolah Dasar, Fakultas Ilmu Pendidikan, Universitas PGRI Semarang
}

\author{
A R T I C L E I N F O \\ Article history: \\ Received 10 February \\ 2019 \\ Received in revised form \\ 09 March 2019 \\ Accepted 15 April 2019 \\ Available online 25 May \\ 2019 \\ Kata Kunci: \\ Number Head Together \\ Puzzle, Hasil Belajar \\ Keywords: \\ Number Head Together, \\ Puzzle, \\ Learning Outcomes.
}

\begin{abstract}
A B S T R A K
Penelitian ini bertujuan untuk mengidentifikasi efektif atau tidaknya model pembelajaran Number Head Together (NHT) berbantu media Puzzle terhadap hasil belajar Matematika siswa kelas IV SDN 01 Damarjati Jepara. Jenis penelitian ini adalah penelitian kuantitatif. Desain penelitian yang digunakan dalam penelitian ini adalah PreEksperimental Design dengan bentuk One Grup Pretest-Posttest Design. Populasi penelitian ini adalah seluruh siswa kelas IV SDN 01 Damarjati Jepara dengan menggunakan teknik Non Probability Sampling yang merupakan jenis sampling jenuh. Data dalam penelitian ini diperoleh melalui tes, dokumentasi dan wawancara. Analisis data menggunakan teknik analisis uji normalitas awal akhir dan uji hipotesis (uji t). Uji normalitas digunakan untuk mengetahui hasil belajar siswa tersebut berdistribusi normal atau tidak. Uji hipotesis menggunakan ttest. Berdasarkan hasil analisis data penelitian menunjukkan koefisien uji t sebesar 14,175 dan koefisien tersebut signifikan pada taraf $5 \%$. Rata-rata nilai sebelum diberi perlakuan adalah 51 yang berarti kurang
\end{abstract} dari KKM dan rata-rata nilai setelah diberi perlakuan adalah 78 yang berarti sudah memenuhi KKM. Selisih rata-rata kenaikannya sebesar 27. Oleh karena itu dapat disimpulkan bahwa penggunaan model pembelajaran Number Head Together (NHT) Berbantu Media Puzzle efektif terhadap hasil belajar Matematika siswa kelas IV SDN 01 Damarjati Jepara tahun ajaran 2018/2019.

\section{A B S T R A C T}

This study aims to identify the effectiveness of the Puzzle Media Number Head Together (NHT) learning model on Mathematics learning outcomes of fourth grade students of SDN 01 Damarjati Jepara. This type of research is quantitative research. The research design used in this study is PreExperimental Design in the form of One Group Pretest-Posttest Design. The population of this study was all fourth grade students of SDN 01 Damarjati Jepara using the Non Probability Sampling technique which is a type of saturated sampling. Data in this study were obtained through tests, documentation and interviews. Data analysis using the analysis of the final initial normality test and hypothesis testing ( $t$ test). normality test is used to find out the student learning outcomes are normally distributed or not. Hypothesis testing using t-test. Based on the results of the research data analysis, the $t$ test coefficient is 14,175 and the coefficient is significant at the level of $5 \%$. The average value before being given treatment is 51 which means less than KKM and the average value after being given treatment is 78 which means it has fulfilled the KKM. The difference in average increases is 27. Therefore, it can be concluded that the use of Media Puzzle Assisted Number Head Together (NHT) learning model is effective for Mathematics learning outcomes of fourth grade students of SDN 01 Damarjati Jepara academic year 2018/2019.

\section{Pendahuluan}

Pendidikan merupakan bidang yang sangat penting terutama di Indonesia. Kata Pendidikan berdasarkan KBBI berasal dari kata 'didik' dan kemudian mendapat imbuhan 'pe' dan akhiran 'an', maka kata ini mempunyai arti proses atau cara atau perbuatan mendidik. Secara bahasa definisi pendidikan

Copyright (C) Universitas Pendidikan Ganesha. All rights reserved. 
adalah proses pengubahan sikap dan tata laku seseorang atau kelompok orang dalam usaha mendewasakan manusia melalui upaya pengajaran dan pelatihan yang sesuai prosedur pendidikan itu sendiri.

Sebagaimana dicantumkan pada UU No. 20 Tahun 2003 tentang Sistem Pendidikan Nasional menyatakan bahwa Pendidikan adalah usaha sadar dan terencana untuk mewujudkan suasana belajar dan proses pembelajaran agar peserta didik secara aktif mengembangkan potensi dirinya untuk memiliki kekuatan spiritual keagamaan, pengendalian diri, kepribadian, kecerdasan, akhlak mulia, serta keterampilan yang diperlukan dirinya, masyarakat, bangsa dan negara.

Undang-undang inilah yang menjadi dasar berdirinya proses pendidikan yang ada di negara Indonesia. Tujuan pendidikan nasional adalah mencerdaskan kehidupan bangsa dan mengembangkan manusia Indonesia seutuhnya. Negara Indonesia ini merupakan negara yang berkembang dan berupaya untuk meningkatkan kualitas pendidikan seperti pada tujuan nasional. Dalam meningkatkan kualitas pendidikan itu sendirinya diantaranya terletak pada kualitas guru. Maka dari itu sejak dini mungkin diterapkanlah pendidikan yang mempunyai kualitas baik, sehingga dapat mempengaruhi kualitas pendidikan di Indonesia dan sesuai dengan harapan tujuan nasional pendidikan.

Menurut (Dwirahayu \& Nursida, 2016) matematika diakui sebagai salah satu mata pelajaran yang dianggap sulit dan juga menakutkan. Hal ini menjadi pekerjaan rumah bagi guru matematika untuk mengubah pendapat kebanyakan orang tentang matematika. Pada tingkat dasar pun sebagian besar siswa kurang menyukai matematika karena matematika banyak rumus yang harus dihafal jadi sulit untuk difahami. Menurut (Dzulfikar \& Ciptianingsari, 2017) matematika merupakan ilmu yang diajarkan secara bertahap dan menggunakan metode spiral. Matematika diajarkan mulai dari tahap konkret, semi konkret, kemudian abstrak. Matematika juga diajarkan dari konsep-konsep sederhana hingga konsep yang kompleks. Matematika yang bersifat hirarkis dimana antara satu topik dengan topik lainnya saling terkait, mengharuskan siswa memiliki pemahaman yang baik terhadap konsep untuk belajar konsep lainnya. Menurut (Widyastuti \& Pratiwi, 2014) matematika merupakan ilmu dasar yang mendasari perkembangan ilmu-ilmu lain. Oleh karena itu matematika menjadi salah satu mata pelajaran yang penting untuk diajarkan di sekolah. Ungkapan "Mathematics for life" and "mathematics as a human activities" yang diutarakan oleh Freudethal mengartikan bahwa matematika merupakan sebuah aktivitas yang berlaku dan bermanfaat dalam kehidupan sehari-hari. Setiap aktivitas manusia dalam kehidupan sehari-hari tidak lepas dari peran matematika. Matematika merupakan salah satu bidang studi yang ada paa semua jenjang pendidikan, mulai dari tingkat sekolah dasar hingga perguruan tinggi. Bahkan matematika diajarkan di taman kanak-kanak secara informal (Susanto, 2015: 183). Tujuan pembelajaran matematika di sekolah dasar adalah agar siswa mampu dan terampil menggunakan matematika, tetapi dapat memberikan bekal kepada siswa dengan tekanan penataan nalar dalam penerapan matematika dalam kehidupan sehari-hari di tengah-tengah masyarakat di mana ia tinggal.

Namun kenyataannya mata pelajaran matematika seringkali dijadikan momok atau permasalahan oleh siswa, bahwa pelajaran matematika dianggap pelajaran yang sulit, pelajaran yang menakutkan, sehingga dalam menerima pemahaman konsep yang diberikan oleh guru siswa kurang menerima. Disampin siswa kurang menerima atau memahami konsep yang diberikan oleh guru siswa juga tidak berani bertanya kepada guru tentang materi yang belum dimengerti. Sehingga nilai ynag dihasilkan siswa tak jarang kurang dari KKM yang sudah ditentukan yaitu 65 dengan rata-rata kelas 60. Dengan jumlah siswa kelas IV yaitu 30 siswa terdiri dari 12 laki-laki dan 18 perempuan. Hal tersebut diperoleh dari nilai Ulangan Harian siswa mata pelajaran Matematika masih terdapat 33\% siswa yang belum memahami mata pelajaran Matematika pada materi bangun datar dari Kriteria Ketuntasan Minimal (KKM) yang ditentukan pada mata pelajaran Matematika yaitu 65.

Nilai Ulangan Harian siswa kelas IV di SDN 01 Damarjati Jepara pada mata pelajaran Matematika masih terdapat sebanyak 33\% siswa belum memenuhi KKM. Berdasarkan hasil wawanara dengan guru kelas IV hal tersebut dikarenakan proses pembelajaran Matematika kurang menggunakan alat peraga sebagai media penunjang dan guru masih menggunakan model konvensional. Proses pembelajaran tersebut menyebabkan banyak siswa yang tidak memperhatikan saat dijelaskan, akibatnya siswa kurang aktif bertanya dan menjawab pertanyaan.

Permasalahan diatas perlu adanya perubahan pembelajaran, dimana pembelajaran yang semula berpusat pada guru menuju pembelajaran yang berpusat pada siswa. Kurangnya pengunaan model-model pembelajaran untuk meningkatkan hasil belajar siswa. Ada satu perubahan yang dapat dilakukan menggunakan model pembelajaran kooperatif.

Menurut Joyce (dalam Al-Tabany, 2017 : 23) model pembelajaran adalah suatu perencanaan atau suatu pola yang dipersiapkan dan digunakan sebagai pedoman dalam merencanakan pembelajaran di kelas atau pembelajaran dalam tutorial untuk menentukan perangkat-perangkat pembelajaran termasuk di dalamnya buku, film, komputer, kurikulum, dan lain-lain. Merancang bahan-bahan pembelajaran, dan 
membimbing pembelajaran di kelas atau yang lain. Menurut Sudarwati dkk, (2014) metode kooperatif mampu membangkitkan motivasi siswa agar mampu berperan secara aktif dalam kegiatan pembelajaran. NHT merupakan teknik mengajar yang efektif dan efisien untuk meningkatkan prestasi belajar. Metode tersebut memberikan peluang kepada siswa untuk membangun pengetahuannya sendiri dan menggunakan konsep-konsep yang sudah dimiliki untuk memecahkan masalah secara kelompok. Kesuksesan kelompok ditentukan oleh peran anggota. Untuk meningkatkan prestasi kelompok, maka setiap anggota harus berprestasi. Menurut (Mulyana, dkk, 2016) dengan pembelajaran kooperatif tipe NHT ini akan membuat siswa tidak jenuh dalam kegiatan pembelajaran dan siswa dapat sharing dengan teman-temannya untuk memecahkan permasalahan yang diberikan oleh guru, karena guru hanya sebagai fasilitator untuk mengembangkan pengetahuan siswa, serta mampu membuat siswa mampu bertanggung jawab lebih baik lagi yang pada akhirnya akan meningkatkan hasil belajar siswa menjadi lebih baik. Menurut (Astrawan, 2015) NHT digunakan untuk melibatkan lebih banyak siswa dalam menelaah materi yang tercakup dalam suatu pelajaran dan mengecek pemahaman mereka terhadap isi pelajaran tersebut. NHT sebagai model pembelajaran pada dasarnya merupakan sebuah variasi diskusi kelompok. Adapun ciri khas dari NHT adalah guru hanya menunjuk seorang siswa yang mewakili kelompoknya. Dalam menujuk siswa tersebut, guru tanpa memberi tahu terlebih dahulu siapa yang akan mewakili kelompok tersebut. NHT merupakan tipe pembelajaran kooperatif yang terdiri atas empat tahap yang digunakan untuk mereview fakta-fakta dan informasi dasar yang berfungsi untuk mengatur interaksi siswa.

Selain menggunakan model pembelajaran Number Head Together, penelitian ini juag berbantuan media Puzzle. Puzzle merupakan permianan anak-anak yang dapat meningkatkan pemahaman konsep tentang bangun-bangun datar. Puzzle juga dapat dijadikan sebagai media pembelajaran yang edukatif dan menarik. Menimbulkan keaktifan dan perhatian siswa dalam proses pembelajaran, dan membantu guru dalam mencapai tujuan pembelajaran.

Berdasarkan masalah yang dipaparkan di atas, penulis mengajukan sebuah penelitian dengan judul keefektifan model pembelajaran Number Head Together (NHT) berbantu media Puzzle terhadap hasil belajar matematika kelas IV SDN 01 Damarjati Jepara.

\section{Metode}

Penelitian ini dilaksanakan di SD Negeri 01 Damarjati Jepara. Penelitian ini dilakukan pada tanggal 15 Mei sampai 17 Mei 2019 pada tahun pembelajaran 2018/2019.

Dalam penelitian ini terdapat dua variabel, yaitu variabel bebas dan variabel terikat: 1) Variabel Bebas (X), adalah variabel yang mempengaruhi atau yang menjadi sebab perubahan. Variabel bebas pada penelitian ini yaitu model pembelajaran Number Head Together dan 2) Variabel Terikat (Y), adalah variabel yang dipengaruhi atau yang menjadi akibat, karena adanya variabel bebas. Variabel terikat pada penelitian ini adalah hasil belajar dan motivasi belajar pada mata pelajaran Matematika siswa kelas IV SD Negeri 01 Damarjati Jepara.

Metode penelitian yang digunakan dalam penelitian ini adalah pre-experimental design dengan bentuk one-group pretest-posttest design. Menurut Sugiyono, (2016: 110-111) dalam desain ini menggunakan pretest sebelum diberi perlakuan dengan demikian hasil perlakuan dapat diketahui lebih akurat, karena dapat membandingkan dengan keadaan sebelum diberi perlakuan.

Sugiyono, (2016: 117) populasi adalah wilayah generalisasi yang terdiri atas: obyek/subyek yang mempunyai kualitas dan karakteristik tertentu yang ditetapkan oleh peneliti untuk dipelajari dan kemudian ditarik kesimpulnya. Populasi dalam penelitian ini adalah keseluruhan siswa kelas IV SD Negeri 01 Damarjati Jepara.

Sampel adalah bagian dari jumlah dan karakteristik yang dimiliki oleh populasi tersebut (Sugiyono, 2016: 118). Sampel dalam penelitian ini adalah keseluruhan siswa kelas IV SD Negeri 01 Damarjati Jepara sebanyak 30 Siswa yang terdiri dari 12 siswa laki-laki dan 18 siswa perempuan.

Teknik sampling adalah merupakan teknik pengambilan sampel (Sugiyono, 2016: 118). Teknik sampling yang digunakan dalam penelitian ini adalah nonprobability sampling. Nonprobability sampling adalah teknik pengambilan sampel yang tidak memberi peluang/kesempatan sama bagi setiap unsur atau anggota populasi untuk dipilih menjadi sampel. Sampling yang digunakan dalam peneltian ini adalah sampling jenuh. Sampling jenuh adalah teknik penentuan sampel bila semua anggota populasi digunakan sebagai sampel.

Teknik pengumpulan data menggunakan wawancara, dokumentasi, tes, dan angket. Teknik analisis instrumen penelitian berupa uji validitas, reliabilitas, daya pembeda dan taraf kesukaran.

Teknik analisis data berupa analisis data adapun rumus yang digunakan uji normalitas awal (pretest) dan uji normalitas akhir (posttest). Kemudian menggunakan rumus uji $\mathrm{t}$ atau uji hipotesis selanjutnya uji ketuntasan belajar berupa uji ketuntasan belajar individual dan uji ketuntasan belajar 
klasikal. Dengan kriteria siswa telah menguasai sekurang-kurangnya 65\% terhadap materi setiap bahasan yang diajukan. Ketuntasan individu dan klasikal $\geq 65$ tuntas.

\section{Hasil dan Pembahasan}

Hasil penelitian di SD Negeri 01 Damarjati Jepara pada semester II tahun ajaran 2018/2019 pada kelas IV dengan jumlah 30 siswa. Kegiatan pembelajaran pada penelitian ini adalah menerapkan model pembelajaran Number Head Together (NHT) berbantu media Puzzle terhadap hasil belajar Matematika siswa kelas IV SD Negeri 01 Damarjati Jepara.

Pada penelitian ini desain yang digunakan adalah desain penelitian Pre-Experimental Desain dengan bentuk One Group Pretest-Posttest Design, dimana siswa diberi Pretest untuk mengetahui nilai awal sebelum diberi perlakuan. Setelah diberi perlakuan dengan menggunakan model Number Head Together berbantu media Puzzle kemudian siswa diberi Posttest untuk mengetahui keefektifan penggunaan model dan media tersebut.

Penelitian awal peneliti melakukan uji coba soal instrument untuk menghitung validitas, reliabilitas, daya pembeda, dan taraf kesukaran soal di SD Negeri 01 Damarjati Jepara pada kelas V. Soal uji coba instrument berupa soal pilihan ganda sebanyak 50 butir soal dan dikerjakan oleh 20 siswa. Setelah dilakukan analisis butir soal peneliti melakukan penelitian di SD Negeri 01 Damarjati Jepara pada kelas IV. Siswa diberikan pretest untuk mengetahui kemampuan awal siswa sebelum diberikan perlakuan oleh peneliti dengan menggunakan model pembelajaran Number Head Together (NHT) berbantu media Puzzle. setelah siswa diberika perlakuan oleh peneliti, maka siswa diberikan posttest untuk mengetahui kemampuan akhir siswa dengan menggunakan model pembelajaran Number Head Together (NHT) berbantu media Puzzle. Rekapitulasi nilai siswa dapat dilihat pada tabel 1 di bawah ini.

Tabel 1. Data hasil Pretest dan Posttest

\begin{tabular}{|c|c|c|}
\hline \multirow{2}{*}{ Keterangan } & \multicolumn{2}{|c|}{ Kelas IV } \\
\hline & Pretest & Posttest \\
\hline Nilai Tertinggi & 68 & 92 \\
\hline Nilai Terendah & 32 & 68 \\
\hline Rata-rata & 50 & 80 \\
\hline
\end{tabular}

Berdasarkan data yang terdapat pada tabel 1 diperoleh nilai tertinggi pretest yaitu 68 sedangkan nilai tertinggi posttest yaitu 92. Kemudian untuk nilai terendah pretest yaitu 32 dan nilai terendah posttest yaitu 68. Selanjutnya untuk nilai rata-rata pretest yaitu 50,1 sedangkan nilai rata-rata posttest yaitu 78,4 dapat dilihat pada gambar 4.3. dengan demikian menunjukkan bahwa kelas saat diberi perlakuan Model Number Head Together berbantu Media Puzzle mendapatkan nilai rata-rata lebih tinggi daripada sebelum diberi perlakuan.

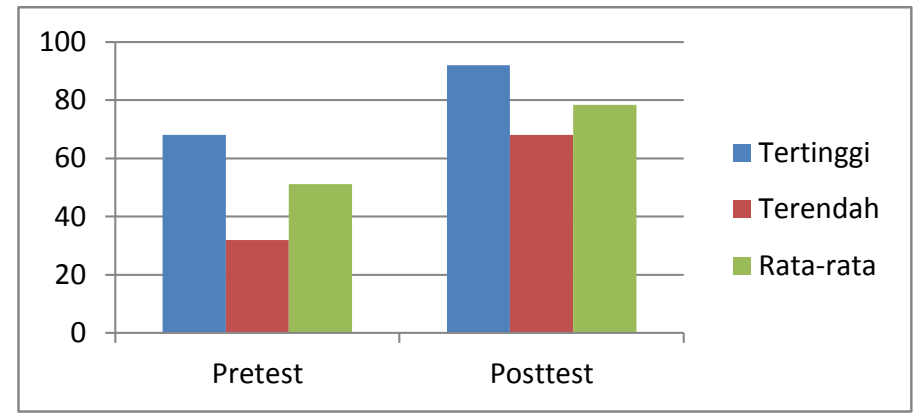

Gambar 1 Selisih Nilai Rata-rata Pretest Posttest

Berdasarkan diagram 1 menunjukkan bahwa terdapat peningkatan antara nilai pretest sebelum diberikan perlakuan dengan nilai posttest yang sudah diberikan perlakuan denggan menggunakan model pembelajaran Number Head Together (NHT) berbantu media Puzzle. Hasil nilai pada penelitian ini yang dijadikan sebagai data akhir penelitian yaitu nilai posttest. Data yang diperoleh selanjutnya digunakan untuk menghitung uji normalitas dan uji t. 
Sebelum menghitung uji normalitas dan uji t, peneliti terlebih dahulu menghitung kemampuan siswa dalam menerapkan dan menggunakan media puzzle secara berkemlompok. Adapun nilai yang dihitung adalah nilai afektif dan nilai psikomotor.

Tabel 2. Hasil Penilaian Afektif

\begin{tabular}{cccc}
\hline Sikap & Pertemuan I & Pertemuan II & Pertemuan III \\
\hline Tertinggi & 82 & 93 & 100 \\
Terendah & 73 & 73 & 73 \\
Rata-rata & 77,5 & 83 & 86,5 \\
\hline
\end{tabular}

Dari data yang tertera pada tabel dapat dilihat bahwa penilaian afektif dari pembelajaran pertama hingga ketiga mengalami kenaikan. Aspek afektif yang dinilai yaitu rasa ingin tahu, percaya diri dan kerjasama dengan kriteria yang sudah ditentukan. Dari pembelajaran pertama hingga kedua rata-rata nilai afektif meningkat sebesar 7,5 sedangkan dari pembelajaran kedua hingga ketiga rata-rata nilai afektif meningkat sebesar 3,5. Data kenaikan nilai afektif dapat dilihat pada gambar 2.

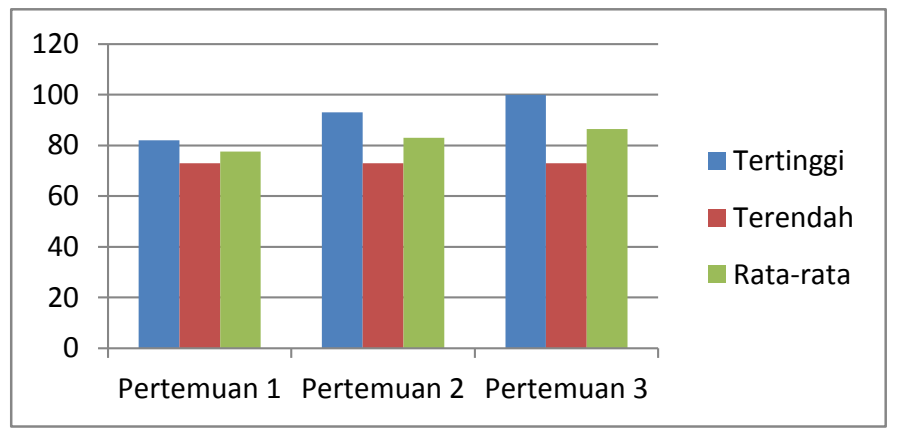

Gambar 2 Diagram Hasil Penilaian Afektif

Berdasarkan diagram 2 menunjukkan bahwa terdapat peningkatan niali afektif setiap pertemuannya antara nilai yang sudah diberikan perlakuan denggan menggunakan model pembelajaran Number Head Together (NHT) berbantu media Puzzle.

Tabel 3 Hasil Penilaian Psikomotor

\begin{tabular}{cccc}
\hline Keterampilan & Pertemuan 1 & Pertemuan 2 & Pertemuan 3 \\
\hline Tertinggi & 87 & 91 & 100 \\
Terendah & 75 & 75 & 75 \\
Rata-rata & 81 & 83 & 87,5 \\
\hline
\end{tabular}

Dari data yang tertera pada tabel dapat dilihat bahwa penilaian psikomotor dari pembelajaran pertama hingga ketiga mengalami kenaikan. Aspek psikomotor yang dinilai yaitu keterampian menggunakan media dan keterampilan menyampaikan hasil diskusi. Dari pembelajaran pertama hingga kedua rata-rata nilai meningkat sebesar 2,0 sedangkan dari pembelajaran kedua hingga ketiga rata-rata nilai meningkat sebesar 4,5. Data kenaikan nilai psikomotor dapat dilihat pada gambar 4.5. 


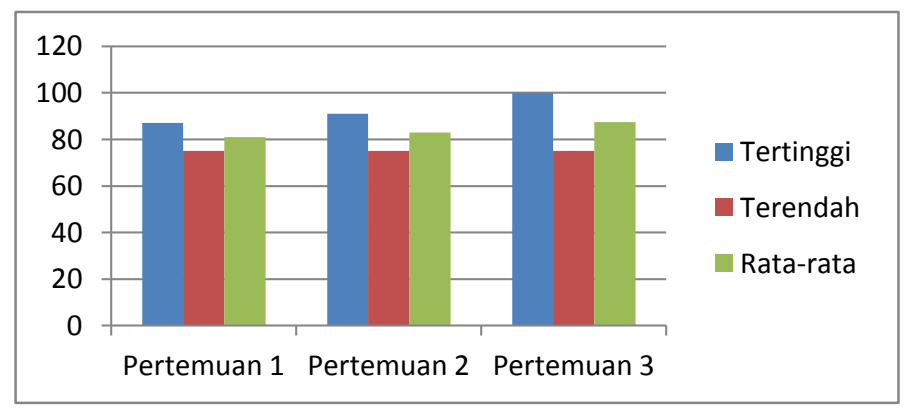

Gambar 3 Diagram Hasil Penilaian Psikomotor

Berdasarkan diagram 3 menunjukkan bahwa terdapat peningkatan niali psikomotor setiap pertemuannya antara nilai yang sudah diberikan perlakuan denggan menggunakan model pembelajaran Number Head Together (NHT) berbantu media Puzzle.

Tabel 4 Hasil Uji Normalitas Pretest (Awal)

\begin{tabular}{ccc}
\hline NO & DATA & \\
\hline 1 & Jumlah & 1532 \\
2 & Rata-rata & 51,07 \\
3 & $\mathrm{~S}$ & 10,75 \\
4 & $\mathrm{~L}_{0}$ & 0,120 \\
5 & $\mathrm{~L}$ tabel & 0,161 \\
\hline
\end{tabular}

Kesimpulan : $\mathrm{L}_{0}<$ Ltabel maka $\mathrm{H}_{0}$ diterima artinya data berdistribusi normal. Berdasarkan data hasil perhitungan yaitu uji normalitas Pretest pada kelas IV didapatkan nilai Lhitung sebesar 0,120 sedangkan $\mathrm{L}_{\text {tabel }} 0,161$. Berarti $\mathrm{L}_{\text {hitung }} 0,120<\mathrm{L}_{\text {tabel }} 0,161$ maka $\mathrm{H}_{0}$ diterima. Hal ini berarti sampel berasal dari populasi berdistribusi normal.

Tabel 5 Hasil Uji Normalitas Posttest (Akhir)

\begin{tabular}{ccc}
\hline NO & DATA & \\
\hline 1 & Jumlah & 2352 \\
2 & Rata-rata & 78,40 \\
3 & S & 5,81 \\
4 & Lo & 0,159 \\
5 & Ltabel & 0,161 \\
\hline
\end{tabular}

Kesimpulan : Lo < Ltabel maka $\mathrm{H}_{0}$ diterima artinya data berdistribusi normal. Berdasarkan hasil perhitungan normalitas yaitu uji normalitas Posttest pada kelas IV didapatkan nilai Lhitung sebesar 0,159 dengan harga Ltabel $=0,161$. Berarti Lhitung $0,159<$ Ltabel 0,161 maka $\mathrm{H}_{a}$ diterima. Hal ini berarti sampel berasal dari populasi berdistribusi normal.

Tabel 6 Hasil Belajar (uji t)

\begin{tabular}{cccc}
\hline NO & DATA & PRETEST & POSTTEST \\
\hline 1 & Jumlah & 1503 & 2352 \\
2 & Rata-rata & 50,1 & 78,4 \\
3 & Md & & 27,33 \\
4 & thitung & \multicolumn{2}{c}{14,175} \\
5 & tabel & 2,042 & \\
\hline
\end{tabular}

Berdasarkan perhitungan diperoleh thitung sebesar 14,175 sedangkan $t_{\text {tabel }} 2,042$ dengan $\mathrm{db}=\mathrm{N}-1=$ 30-1 = 29, dan taraf signifikan sebesar 0,05. Karena thitung $>$ tabel yaitu 14,175 $>2,042$ maka $\mathrm{H}_{0}$ ditolak dan $\mathrm{H}_{a}$ diterima. Sehingga dapat dikatakan bahwa model pembelajaran Number Head Togetehr berbantu media Puzzle efektif terhadap hasil belajar siswa kelas IV SDN 01 Damarjati Jepara. 
Model dan media pembelajaran memang seharusnya diberikan guru kepada siswa. Kejenuhan dalam pembelajaran dapat diminimalisir dengan penggunaan model dan media pembelajaran yang baru. Penggunaan model dan media pembelajaran tersebut tentunya akan dapat menarik perhatian siswa dalam menerima pembelajaran di kelas. Contohnya model pembelajaran Number Head Together berbantu media Puzzle yang dapat menjadikan siswa lebih aktif selama mengikuti pembelajaran di kelas. Terlebih lagi pada pembelajaran Matematika yang dekat dengan kehidupan keseharian siswa, sehingga media Puzzle dapat mendukung pembelajaran untuk menumbuhkan semangat dan minat belajar siswa.

Kejenuhan pada siswa dapat dilihat dari hasil belajar yang kurang maksimal. Masih banyak siswa di SDN 01 Damarjati Jepara yang mendapatkan nilai Matematika dibawah Kriteria Ketuntasan Minimal (KKM) yaitu sebesar 65. Hal ini dikarenakan guru saat mengajar masih menggunakan metode ceramah dan belum menerapkan variasi pembelajaran yang lebih menarik.

Model pembelajaran Number Head Together merupakan pembelajaran yang yang memberikan kesempatan pada siswa untuk saling membagikan ide-ide dan mempertimbangkan jawaban yang paling tepat. Selain itu model pembelajaran ini juga mendorong siswa untuk meningkatkan semangat kerjasama siswa. Sedangkan media Puzzle merupakan media yang dibuat untuk membuat siswa lebih aktif dan menumbuhkan semangat dan ingatan siswa lebih mendalam dikarenakan munculnya motivasi untuk senantiasa mencoba memecahkan masalah khususnya pada mata pelajaran Matematika.

Untuk itu, peneliti melakukan penelitian di SDN 01 Damarjati Jepara tahun pelajaran 2018/2019. Sampel dalam penelitian ini diambil dengan non probability sampling dengan jenis sampling jenuh. Dalam penelitian ini subyek penelitian adalah siswa kelas IV dengan jumlah siswa 30 siswa. Penelitian ini menggunakan desain penelitian Pre-Experimental Desain dengan bentuk One Group Pretest-Posttest Design. Hasil yang baik adalah apabila nilai Posttest lebih besar dari Pretest.

Berdasarkan hasil analisis uji oba instrument dengan mempertimbangkan validitas, reliabilitas, tingkat kesukaran, dan daya pembeda maka didapatan 26 soal memenuhi kriteria dari 50 soal uji coba instrument. Kemudian dipilih 25 dari 26 soal uji coba yang memenuhi kriteria tersebut digunakan untuk Pretest dan juga Posttest.

Data awal penelitian menggunakan data dari nilai Pretest siswa. Rata-rata nilai Pretest yaitu sebesar 50,1. Berdasarkan uji normalitas awal, data awal penelitian yang berasal dari nilai Pretest siswa adalah berdistribusi normal. Hal tersebut dibuktikan dengan hasil Lhitung sebesar 0,120 sedangkan Ltabel $=0,161$. Berarti Lhitung 0,120<0,161 Ltabel. Rata-rata hasil Pretest yang diperoleh masih rendah dikarenakan proses pembelajaran yang berlangsung bersifat monoton. Belum digunakannya model dan media pembelajaran sehingga siswa cenderung bosan untuk mengikuti pembelajaran.

Data akhir penelitian menggunakan data dari nilai Posttest siswa yaitu untuk mengetahui hasil belajar siswa setelah diberi perlakuan. Berdasarkan uji normalitas, data akhir penelitian dari nilai Posttest adalah berdistribusi normal. Hal tersebut dibuktikan dengan Lhitung 0,159<0,161 Ltabel maka $\mathrm{H}_{0}$ diterima. Pada analisis akhir menggunakan uji t diperoleh hasil thitung sebesar 14,175 sedangkan tabel 2,042 dengan $\mathrm{db}=\mathrm{N}-1=30-1=29$, dan taraf signifikan 0,05. Karena thitung $>$ tabel yaitu 14,175 $>2,042$ maka $\mathrm{H}_{0}$ ditolak dan $\mathrm{H}_{a}$ diterima. Sehingga dapat dikatakan bahwa model pembelajaran Number Head Together berbantu media Puzzle efektif terhadap hasil belajar siswa kelas IV SDN 01 Damarjati Jepara.

Berdasarkan uraian di atas dapat diketahui bahwa pembelajaran dengan menggunakan model Number Head Together berbantu media Puzzle efektif terhadap hasil belajar siswa. Hasil penelitian menunjukkan bahwa penggunaan model Number Head Together berbantu media Puzzle juga membantu guru dalam mengelola kelas selama pembelajaran berlangsung. Hal ini dikarenakan siswa lebih tertarik, merasa senang serta dapat mendukung dan membantu keaktifan siswa selama proses pembelajaran.

Hal ini menunjukkan bahwa model Number Head Together berbantu media Puzzle efektif terhadap hasil belajar siswa kelas IV khususnya pada mata pelajaran Matematika materi bangun datar. Selain itu, dari hasil nilai Posttest menunjukkan bahwa hasil belajar siswa meningkat dari sebelumnya yaitu nilai Pretest.

Menurut pendapat Bloom, klasifikasi belajar secara garis besar menjadi tiga ranah, yakni ranah kognitif, ranah afektif dan ranah psikomotorik (Dimyati; Mudjiono, 2013). Pelaksanaan penelitian ini diberikan Pretest diawal pembelajaran untuk mengetahui pengetahuan siswa (kognitif), setelah itu peneliti memberikan perlakuan (treatment) dengan menggunakan model pembelajaran Number Head Together berbantu media puzzle. Model pembelajaran Number Head Together dapat membuat siswa senang saat mengikuti proses pembelajaran, karena dengan model ini siswa dapat bermain sambil belajar.

Dikemukakan juga oleh Hamalik dalam (Arsyad, 2014: 19) bahwa pemakaian media pembelajaran dapat membangkitkan keinginan dan minat yang baru, membangkitkan motivasi dan rangsangan kegiatan belajar, dan bahkan membawa pengaruh-pengaruh psikologis terhadap siswa. Kekuatan puzzle untuk mempengaruhi pikiran siswa terletak pada keseriusan dan ketelitian siswa merangkai puzzle untuk membentuk beberapa bangun datar. 
Media puzzle memudahkan siswa untuk memahami apa yang dimaksudkan oleh guru ketika menyampaiakan materi pembelajaran, siswa cepat tanggap atas materi yang disampaikan karena diiringi dengan gambar-gambar. Siswa lebih berkonsentrasi dan merasa asyik karena tugas yang diberikan oleh guru berkaitan dengan permainan mereka sehari-sehari. Menarik bagi siswa dikarenakan melalui visual dalam bentuk bangun datar nyata, sehingga siswa akan lebih aktif dan hasil belajar semakin meningkat.

Setelah dilakukan perlakuan, peneliti memberikan Posttest untuk mengetahui hasil belajar siswa setelah menggunakan model pembelajaran Number Head Together berbantu media puzzle. Peneliti membandingkan hasil belajar dari nilai pretest sebagai data awal dan nilai Posttest sebagai data nilai akhir. Nilai pretest merupakan hasil belajar dari pembelajaran yang sebelum menggunakan model pembelajaran Number Head Together berbantu media puzzle, sedangkan nilai posttest merupakan hasil belajar dari pembelajaran yang setelah menggunakan model pembelajaran Number Head Together berbantu media puzzle. Setelah diberikan perlakuan menggunakan model pembelajaran Number Head Together berbantu media puzzle diperoleh nilai rata-rata hasil belajar pada Posttest meningkat dibandingkan pada nilai ratarata hasil belajar pada pretest. Pada saat pretest didapatkan nilai rata-rata sebesar 50,1, sedangkan setelah diberikan perlakuan dengan menggunakan model pembelajaran Number Head Together berbantu media puzzle didapatkan nilai rata-rata posttest sebesar 78,4. Dengan demikian terjadi peningkatan nilai dari sebelum dan setelah menggunakan model pembelajaran Number Head Together berbantu media puzzle.

Selain mengalami peningkatan pada hasil belajar siswa yang berupa aspek kognitif, pembelajaran menggunakan model pembelajaran Number Head Together berbantu media puzzle juga dapat meningkatkan penilaian aspek afektif. Aspek afektif yang dinilai meliputi rasa ingin tahu yang ketika guru menyampaikan materi, percaya diri yaitu ketika menyampaiakn hasil diskusi dan kerjasama yaitu ketika menggunakan media secara berkelompok. Dari hasil penelitian dapat dilihat peningkatan aspek afektif yang signifikan. Pada pembelajaran pertama rata-rata nilai kelas sebesar 77,5, sedangkan pada pembelajaran kedua terjadi peningkatan dengan rata-rata nilai kelas sebesar 83, selanjutnya pada pembelajaran ketiga sama halnya terjadi peningkatan dengan rata-rata nilai kelas sebesar 86,5 . Sehingga dapat disimpulkan bahwa terjadi perubahan sikap siswa yang lebih baik.

Dalam ranah psikomotorik terdapat dua kriteria yang dinilai yaitu siswa mampu menggunakan media pembelajaran dan siswa mampu menyampaikan hasil diskusi dengan baik. Hal ini dibuktikan peneliti pada data yang telah diperoleh yaitu penilaian psikomotorik pada pembelajaran pertama hingga pembelajaran ketiga mengalami peningkatan nilai rata-rata kelas. Pada pembelajaran pertama mendapatkan rata-rata nilai sebesar 81. Pada kegiatan pembelajaran kedua mendapatkan rata-rata nilai sebesar 83, sedangkan pada kegiatan pembelajaran ketiga mendapatkan rata-rata nilai sebesar 87,5.

Pada pelaksanaan penelitian menggunakan model pembelajaran Number Head Together berbantu media puzzle terdapat beberapa kendala yang dialami oleh peneliti. Salah satu kendala yang dialami oleh peneliti yaitu siswa yang belum terbiasa dengan menggunakan model pembelajaran baru membuat suasana pada pertemuan pertama menjadi kurang efektif. Tetapi hal tersebut dapat diperbaiki pada pertemuan kedua dan ketiga dengan menjelaskan lebih rinci kepada siswa dan siswa mulai terbiasa dengan pembelajaran menggunakan model pembelajaran Number Head Together berbantu media Puzzle sehingga suasana pembelajaran berjalan efektif dan lancar.

\section{Simpulan dan Saran}

Berdasarkan hasil penelitian maka dapat disimpulkan bahwa model pembelajaran Number Head Together berbantu media puzzle efektif terhadap hasil belajar Matematika siswa kelas IV SDN 01 Damarjati Jepara. Hal ini dapat dilihat dari rumusan masalah, pengajuan hipotesis, analisis data penelitian dan pembahasan, maka peneliti membuat kesimpilan pada model pembelajaran Number Head Together berbantu media puzzle. Hasil penelitian dan pembahasan yang diperoleh menunjukkan bahwa hasil nilai Posttest meningkat dari nilai Pretest. Nilai afektif dan nilai psikomotor meningkat dari sebelum diberikan perlakuan dengan setelah diberi perlakuan. Artinya pembelajaran menggunakan model Number Head Together berbantu media puzzle pada siswa SD Negeri 01 Damarjati Jepara efektif untuk mencapai ketuntasan hasil belajar dibandingkan dengan pembelajaran hanya dengan metode ceramah.

Berdasarkan kesimpulan di atas, saran yang dapat peneliti berikan sehubungan dengan hasil penelitian ini adalah model Number Head Together berbantu media puzzle bisa digunakan sebagai variasi pembelajaran yang dapat membuat siswa tidak jenuh dan merasa senang mengikuti pembelajaran Matematika, sehingga materi yang disampaikan dapat diserap dengan baik dan hasil belajar siswa diatas kriteria ketuntasan minimal yang sudah ditentukan.

\section{Daftar Rujukan}

Al-Tabany, T. I. B. (2017). Mendesain Model Pembelajaran Inovatif, Progresif, dan Kontekstual : Konsep, Landasan, dan Implementasinya Pada Kurikulum 2013 (Kurikulum Tematik Integratif KTI) (3rd ed.). 
Jakarta: Kencana.

Arsyad, A. (2014). Media Pembelajaran. Jakarta: PT Raja Grafindo Persada.

Astrawan, I. G. B. (2015). Penerapan Model Kooperatif Tipe NHT dalam Meningkatkan Hasil Belajar Siswa pada Mata Pelajaran IPA di Kelas V SDN 3 Tonggolobibi. Jurnal Kreatif Tadulako, 3(4), 227-242.

Dimyati; Mudjiono. (2013). Belajar dan Pembelajaran. Jakarta: Rineka Cipta.

Dwirahayu, G. N. (2016). Mengembangkan Pembelajaran Matematika dengan Menggunakan Metode Permainan untuk Siswa Kelas 1 MI. Jurnal Matematika Dan Pendidikan Matematika, 5(2), 117-138. Retrieved from http://ejournal.unkhair.ac.id/index.php/.

Dzulfikar, A. C. A. V. (2017). Miskonsepsi Matematika pada Guru Sekolah Dasar. Suska Journal of Mathematics Education, 3(1), 41-48. Retrieved from http://ejournal.uinsuska.ac.id/index.php/SJME/article/view/3409.

Mulyana; Mutia Agisni; Nurdinah Hanifah; Asep Kurnia Jayadinata. (2016). Penerapan Model Kooperatif Tipe Numbered Heads Together (NHT) untuk Meningkatkan Hasil Belajar Siswa pada Materi Kenampakan Alam dan Sosial Budaya. Jurnal Pena Ilmiah, 1(1), 331-340.

Sudarwati; Budi Utami; Kus Sri Martini. (2014). Penerapan Metode Pembelajaran Numbered Heads Together (NHT) untuk Meningkatkan Motivasi dan Hasil Belajar Kelarutan dan Hasil Kali Kelarutan Kelas XI IPA 4 SMAN 8 Surakarta Tahun Pelajaran 2012/2013. Jurnal Pendidikan Kimia (JPK), 3(2), 67-73.

Sugiyono. (2016). Metode Penelitian Kualitatif, Kuantitatif, dan R\&D. Bandung: Alfabeta.

Susanto, A. (2015). Teori Belajar dan Pembelajaran di Sekolah Dasar. Jakarta: Prenadamedia Grup.

Widyastuti, N. S. P. P. (2014). Pengaruh Pendidikan Matematika Realistik Indonesia (PMRI) terhadap Pemahaman Konsep dan Berpikir Logis Siswa. Jurnal Prima Edukasia, 2(2), 183-193. Retrieved from https://journal.uny.ac.id/index.php/jpe/article/view/2718/2268. 